\title{
Terrorism and Politico-Religious Extremism in Pakistan Post 9/11
}

\author{
Prof. Dr. Razia Musarrat \\ Chairperson, Department of Political Science \\ The Islamia University of Bahawalpur \\ Bahawalpur, Pakistan \\ Sumaira Khan \\ Department of Political Science \\ The Islamia University of Bahawalpur \\ Bahawalpur, Pakistan
}

Accepted: March 27, 2014

doi:10.5296/ jpag.v4i1.5462 URL: http://dx.doi.org/10.5296/ jpag.v4i1.5462

\begin{abstract}
Pakistan is facing several forms of terrorism, no other country in the world entangled in this problem like Pakistan today. Sectarianism and politico-religious terrorism is an aching problem of Pakistan. The term ethnic refer to the way in which individuals and groups characterize themselves on the basis of their language, race, and place of origin, shared culture, values, and history. Ethnicity is a conception of a common descent, often of a mythic character. A new era of terror began in Pakistan. The situation has become very shocking for the stability of Pakistan. This study investigates terrorism post 9/11 in Pakistan. Terrorism that emerged after $9 / 11$ is the most serious threat. Pakistan has its role as the frontline state in the war against terrorism. The tension between supporters particularly conservative and moderate Islam is growing and the deterioration of composition sate. It is beyond the capacity of single person's effort to eliminate deep rooted crisis of the society. An institutional mechanism with the participation range on a regular basis is the only permanent way to fight against this threat. The study sheds new light on the extent of terrorism, the repeated nature of terrorism, the role of conflict, the choice of weapons, support for terrorism, the choice of targets and the reactionary nature of terrorism.
\end{abstract}

Keywords: Terrorism, Ethnicity, Sectarianism, Talibanaization, Deterioration, Conservative, Reactionary Nature 


\section{Terrorism in Pakistan Post 9/11}

Pakistan became the front line in the war on terrorism after 9/11 incident. The war of Afghanistan changed the scenario of the entire region. Different Afghan groups took part in the formation of Afghan government. Many people of different countries participated in the Afghan war against United States of America. These segments involved in terrorist activities in Pakistan. Pakistan was under the grip of sectarian violence. The people of Pakistan were divided on the issue of Afghan war. The religious extremism was at the peak under the banner of Afghan war. Different violent groups were committing terrorist activities inside or outside Pakistan. Pakistan was surrounded by different terrorist groups which changed the image of Pakistan in the world. There were numerous suicide bombing attacks in different cities of Pakistan. The religious places were not safe. The terrorist organizations made various attacks on defense organization offices and high level officials were also attacked.

US forces were in Afghanistan against the War on terror. Pakistan was non NATO ally, USA declared about Pakistan for its services in the war against terrorism. In American point of view, several terrorist groups were operating in FATA region which are Tehreek-i-Taliban Pakistan, Tehreek-e-Nifaz-e-Shariat-e-Mohammadi, Haqqani network, Al Qaeda, Lashkar-e-Islam and Islamic Movement of Uzbekistan. America started drone attacks in FATA region in 2004.

A characteristic of the ethnic assortment of Pakistan, Afghanistan and Iran is that many ethnic groups are trans-border people. The borders of these countries are divided into major ethnic groups. For Pakistan, each of its major ethnic group is a trans-border group. Punjabis and Sindhis live in both India and Pakistan, but religious cleavages coincide with the national boundaries. A majority of the Baluchis live in Pakistan, but substantial minorities live in Iran and Southern Afghanistan. The Pashtuns are living in Pakistan's Khyber PukhtoonKhwa province, but a majority of the Pukhtoon speakers live in neighboring Afghanistan. The trans-bordering of people may also be created by different extremist feelings in other regions.

In addition to the Pukhtoons, the other linguistic groups in Afghanistan are also divided by international borders. In north, most of the people are Tajiks, Uzbeks, and Turkmens also live in the Soviet side of the border and the Baloch population is divided among Afghanistan, Iran, and Pakistan. The Hazaras are also major ethnic group in Afghanistan.

\section{Incident of World Trade Centre in America}

In Pakistan, new wave of terrorism started when America invaded in Afghanistan after the incident of World Trade Centre. US adopted new policy on the response of World Trade Centre incident. It was considered as global issue and World Terrorism. For this purpose, they started a campaign to counter terrorism. America wanted Pakistan as the frontline friend in war on terrorism. Although in Afghanistan, Pakistan helped them to create Taliban militia with the support of military, logistically and economically, as a result, Taliban occupied ninety percent of Afghan territory. ${ }^{\mathrm{i}}$

US administration made policy to deal with the challenge of terrorism in the light of historical perspective. The effort was made to combat terrorism threats effectively and 
through conventional manners. ${ }^{\text {ii }}$. Pakistan is affected by terrorism being neighbor of Afghanistan. Now terrorism creeps into the heart of Pakistan. Some groups in Pakistan protested against the policy of war on terrorism of Pakistan because Pakistan is US Allies. The US forces used Pakistani military bases and logistic support for operation against Taliban and terrorists sanctuaries in Southern and Eastern Afghanistan bordering on Pakistan's Baluchistan and Khyber PukhtoonKhwa Provinces. ${ }^{\text {iii }}$

US perception was that the incident of $9 / 11$ has revived the rhetoric that Islam is the religion of extremism. It has been argued that the majority of terrorists are Muslims. Walter Laqueur wrote that the current resurgence of religious terrorism is largely identified with trends in Muslims and the Arab World, much to chagrin of those emphasizing the essentially peaceful character of radical Islam find it difficult to account for the fact that in the contemporary world most of the violent conflicts internal and external happened and continue to happen in Muslim countries or in those with active Muslim minorities. There is a wide gap between Western approach and Muslim moderate scholars approach. This creates hurdles to develop the confidence level between the different nations. It may be said that Islam is a peaceful religion and American perception about the Muslims is unsatisfactory because Muslims are not terrorist but the advocate of peace. ${ }^{\text {iv }}$

America needed Pakistan in international coalition against the war on terrorism and was continuously putting pressure on Pakistan. The US demands from Pakistan are given below;

- Sharing of information about Osama

- Sealing of Afghanistan boarder

- Block fuel supplies to Afghanistan

- Allowing the use of airspace ${ }^{\mathrm{v}}$

It was considered that after the death of Osama Bin Laden USA will stay in Afghanistan for long time to keep an eye and control the resources of the region. In this region, many groups opposed the stay of US forces. After $9 / 11$ the radical changes came in US policy, close relations were developed with India at the diplomatic, strategic and military level. The Secretary of State Colin Powell declared, "India has potential to keep the peace in the vast Indian Ocean region and its periphery." ${ }^{\mathrm{vi}}$ Deputy Secretary of State Richard Armitage conveyed message of President Bush to Indian Prime Minister, "to work closely to promote common interest in Asia and beyond" "vii USA forced Pakistan to keep distance from Mullah Omer.

Pakistan was engaged by Washington to achieve notable success. It is imperative to note that USA got success in capturing and killing top leadership of Al Qaeda. America arrested more than 600 people in the suspect of Al-Qaeda and kept them in X-Ray at the Naval base Guantanamo Bay Cuba for two years. America wanted their trial under the military commission. They were not treated as prisoner of war and dealt in criminal courts. ${ }^{\text {viii }}$

Abu Zubaydah (2002), Ramzi bin al-Shibh (2002), Khalid Sheikh Mohammad (2003). Mohammad Naeem Noor Khan (2004) and Abu Faraj al-Libbi leaders of al-Qaeda were 
captured from Pakistan. From these leaders USA obtained future plans and tactics of al-Qaeda. This strategy of engagement had paid for the eastern border with India. There was also tension after parliament attack in India. India logged its armed forces on the international border after Parliament attack. There was danger of war between two nuclear powers of South Asia. USA supported to opt the policy of dialogue, cease-fire and buoyancy between the two countries. "The United States cannot afford Pakistan to fail nor... ignore the extremists operation in Pakistan's tribal areas to operate with impunity". ix

Pakistan's decision to draw back support for Afghanistan lost the military and political significance. ${ }^{\mathrm{x}}$ Pakistan's military ruler supported for the formation of broad based multi ethnic government in Afghanistan. ${ }^{\mathrm{xi}}$ Pakistani decision makers wanted assurance to save and promote the objectives of Pakistan in post Taliban government. Northern Alliance government's interest were different than Pakistan. It was considered that Northern Alliance government was supported by India. Efforts were made to promote Indian interest in Afghanistan and try to de-establish Pakistan with terrorism. 9/11 incident of America changed the scenario of region. America came in the region with long term strategic planning. It was time to start the war on terrorism in the region. Pakistan became active participant of war on terror. War on terrorism started with the mandate of UN. The Security Council of UN approved resolutions. NATO forces started war in Afghanistan.

\section{Analysis of Terrorism Incidents in Pakistan Post 9/11}

After 9/11 America attacked Afghanistan. Pakistan was already facing sectarian violence. As a result, attacks were increased. There were 657 attacks out of which 41 were of sectarian nature resulted in deaths of 907 persons and 1543 were injured according to Pakistan Institute for Peace Studies ,The year of 2009 was worst for Pakistan in which terrorist related incidents resulted in deaths of 3021 and injuries of 7334 reported by Pakistan Security by PIPS. The rate of deaths and injuries were increased. The suicide attack killings were 1300 and injured 3600 people. ${ }^{\text {xii }}$ There were staged terrorist attacks that caused the death of 35000 people out of which 5000 were security enforcement personnel. On the other hand Pakistani economy faced damages of US\$ 67 billion quoted by the World Bank and IMF. ${ }^{\text {xiii }}$

The federal government operated in FATA to destroy the training campuses for the suicide bombings. There was a hope that suicide bombing will be minimized after the operation. According to PIPS report, 86 suicide attacks were made in Pakistan in which 1299 persons were killed and 3633 wounded. The security personnel were 254 who lost their lives in 2009. On the other hand 967 people lost their lives in 2008. After the operation Rah-e-Nijat TTP and its associates responded with desperate suicide attacks in Pakistan. The terrorists changed their strategy and started hitting the public places and bazaars. The choices of suicide bombing were widened.

It was decided by the civil government to maintain writ of government in Khyber PukhtoonKhwa. These groups openly refused to accept the constitution of Pakistan. It became obviously compulsory for state to control over such groups. It was noted about the intensity of terrorist group activities in Pakistan. Terrorist groups targeted Pakistan law enforcement agencies personnel and made much loss to them. These groups were so 
organized and trained in terms of use of advance weapons of war. Therefore modern weapons were used frequently in their specific targets.

The terrorist groups were trained on the pattern of guerilla war. These groups used guerilla war tactics as hand grenade bombs against the law enforcement agencies in Pakistan. There were number of human losses during 2007 in Pakistan. The terrorist groups made targets to both the civilians and law enforcement agencies. There were 1503 terrorist attacks in 2007 included target killings, assassination and suicide attacks in which 3448 casualties and 5353 injuries were reported in these attacks. There were 60 suicide attacks mostly on security forces in which at least 770 died and 1574 injured. It was reported that after Lal Masjid operation violence increased in Pakistan. ${ }^{\text {xiv }}$

Pakistan faced 2148 terrorist attacks in the year 2008. These attacks caused 2267 casualties and 4558 injuries. ${ }^{\mathrm{xv}}$ Human Rights Commission of Pakistan reported that there were 67 suicide attacks in which 973 people were killed and 2318 injured. It was disclosed by the agencies that 140 suicide blasts happened at the end of 2008 in which 56 blasts in $2007 .{ }^{\text {xvi }}$

Some major incidents occurred in response to terrorist activities in Pakistan after 9/11. There were some specific incidents in which human being losses happened as under:

- Daniel Pearl who was a correspondent of Wall Street was killed in Karachi in February 2002. Eleven engineers were also killed in Karachi near five star hotels. These incidents showed the gripe of terrorist groups in major parts of the country and they made their targets almost everywhere in Pakistan.

- First unsuccessful assassination target was President Pervaiz Musharraf on December 2004. It showed high power of terrorist groups to target the top class leaders.

- There was suicide bomb attack in Quetta on March 2004 in which 42 Shias were killed. It was a successful attempt of these groups to boost the sectarian violence.

- There was a series of bomb blast outside the residence of US Consul General and US cultural center in Karachi during 2004.

- There was an attack on the convoy of corps commander Lt. General Asha Hayat in Karachi which caused the death of twelve people. On the other hand attacks on the law enforcement agency officials to down the morale of the forces.

- There was gathering of EidMiladUnNabi at the Nishtar Park in Karachi on April 112006 and there was a bomb blast on religious leaders and more than 50 people lost their lives. ${ }^{\text {xii }}$ It was an effort to spread sectarian violence in Karachi. There was already an intense situation on sectarian scale.

- There was US missile attack in Bajaur on religious madrassa and killed 80 students. There was reaction on the killing of innocent children.

- A suicide attack on Pakistan army soldiers in Daragi on November 8, 2006 and 
42 soldiers were killed in this incident.

- An attack on the police of Peshawar on January 2007 in which 13 people were killed including police chief of Peshawar city.

- Pakistan army's senior medical official Lt. General Mushtaq was killed in suicide attack on February25, 2007.

- There was an assassination on interior minister which resulted the death of 35 people on April 28, 2007.

- Another attempt was made to assassinate President Pervaiz Musharraf in July 6, 2007.

- A suicide attempt was made on army convoy resulted the death of 23 army soldiers on July 14, 2007.

- There were deaths of 49 people including policemen in Swat on July 15, 2007.

- An attack on army soldiers in Rawalpindi on September 4, 2007.

- There were 20 special branch commandoes were killed which were busy in operation against terrorists in secured training place.

- There was suicide bomb blast on the procession of Benazir Bhutto in Karachi on October 18, 2007. There were deaths of 170 people and hundreds of injured. It was attacked on Pakistan famous political leaders when she was coming back to Pakistan after long period for the democratic transition process. It was not only an attack on the leader but on democracy as well.

- The under training 10 military doctors were killed in suicide attack in Rawalpindi.

- There was a suicide attack on Benazir Bhutto's Procession in Rawalpindi on December 27, 2007. The Pakistani prominent leader Benazir Bhutto was killed and hundreds of people were injured. This attack changed the political scenario of Pakistan. The general elections were delayed for short period.

- The 24 officials of intelligence agency were killed in the attack on the headquarters on March 11, 2008.

- There were 13 soldiers killed in a market in Mardan on May 19, 2008.

- There was an attack on Danish Embassy in red security zone in which 6 people were killed.

- There was an attack on police office and 19 policemen were killed on July 6 , 2008.

- The Taliban made attack with bombing on the Marriott Hotel in Islamabad on September 20, 2008 and 57 people killed in this suicide attack. 
- There was attacked on WahCantt factory On August 12, 2008 in which 70 people were killed.

- The militants attacked on GHQ of army in Rawalpindi on October 10, 2009. It was a sign that militants had approached top institutions of Pakistan's defense system.

- Attack was made on Kamrah complex on October 23, 2009. It was continuity of militant attacks on Pakistan defense organization.

- There was bomb blast in Hospital and in bus of Shia followers in which 27 killed 100 injured. ${ }^{\text {xviii }}$

- On April 16, suicide bomb blast in Quetta, DSP and 16 people killed.

- There was made an attack on the Mehran Naval Base Karachi in which two Pakistan P-3C Orion maritime surveillance aircraft were damaged by the terrorists. There was a fight between terrorists and security forces for sixteen hours in which thirteen security men were killed. This attack was made on May 21, 2011. ${ }^{\text {ix }}$

- PAF Kamrah Complex was hit by terrorists on August 16, 2012. One Owax airplane was damaged. This incident shacked out state defense system. Many strategic analysts were astonished at the terrorist action. It was a question mark on state defense system. How other institution could be secured from terrorist groups.

- The attack on the Peshawar airport, once again challenged the security agencies of Pakistan.

Following is a summary of losses of both side of law enforcement agencies and civilians with terrorists from 2003 to June 2009. 
Table 1

Annual Fatalities in Terrorist Violence in Pakistan 2003-2009

\begin{tabular}{|c|c|c|c|c|}
\hline Year & Civilians & $\begin{array}{ll}\text { Security } & \text { Force } \\
\text { Personnel } & \end{array}$ & Terrorists/Insurgents & Total \\
\hline 2003 & 140 & 24 & 25 & 189 \\
\hline 2004 & 435 & 184 & 244 & 863 \\
\hline 2005 & 430 & 81 & 137 & 648 \\
\hline 2006 & 608 & 325 & 538 & 1471 \\
\hline 2007 & 1523 & 597 & 1479 & 3599 \\
\hline 2008 & 2155 & 654 & 3906 & 6715 \\
\hline 2009 (June) & 1222 & 520 & 3938 & 5680 \\
\hline Total & 6532 & 2385 & 10268 & 19165 \\
\hline
\end{tabular}

Source: Mir, Amir, (July 3, 2009). Pakistan turned into suicide capital of the world. ${ }^{\mathrm{xx}}$

In one such drone attack Taliban leader Hakim UllahMasood killed on 31 January 2010. ${ }^{\text {xxi }}$ In North Waziristan Drone Attacks 29 persons were killed on February 2, 2010. Khalid Khwaja was killed in North Waziristan on April 30, 2010, he was an ex-official of ISI.

These incidents showed the weaknesses of law enforcement agencies. The intensity of the incidents showed the terrorist groups ability to challenge the writ of state. There was a weak governing system. There were few examples in which terrorists were given punishment. The state judicial system was weak to give penalty.

\section{The Rise of Islamic Radicalism}

An organization to segregate the society irretrievably on sectarian lines was twisted in Punjab. The simple one point program of the organization was to get rid the country of the shias. Soon the slogan Shias are Kafirs' was appeared on walls all over the country.

There was a country-wide campaign against Shias. Its orators were to deliver scorching speeches against the other sect which were soon to be heard on tape recorders all over the country. It was to challenge them everywhere, and conduct a Jihad against them. The 
sectarian issue took a qualitatively different turn. In response different groups started viciously murdering religious scholars, political activists and professionals of contender sect. various religious groups have exclusivist religious imagination and conflicting interpretations of history and Islam according to their doctrine. Each group challenged the religious authenticity of other. It is proclaimed the other is out of the pale of Islam.

The Sectarian violence got impetus that conflicting groups declared each other non Muslims. There was unabated violence both sides deepened religious schism pursuing a policy of annihilation. There was loss of 7594 lives in sectarian violence since 1989 to April 2011. ${ }^{\text {xii }}$

Thousands of Pakistani had lost their lives in the battle of sectarian terrorism. In this terrorism wave no mosque or other religious places were safe. The rise of radicalism confronted with the religious communities. Shia-Sunni clashes were to be no more spontaneous or confined to a locality. They were to be organized consciously and spread all over the country. Deliberate efforts were made to generate tension and to provoke inter-religious strife.

\section{Extremism and Non Muslims of Pakistan}

The religious intolerance had grown among different sects of Muslims of Pakistan. The extremists had no tolerance against non-Muslim. This wave affected the minorities of Pakistan. There was sense of exclusion, inferiority, discrimination, insecurity and fear of murder. ${ }^{\text {xiii }}$ Wall chalking and posters are often provocative in their attacks on the minorities, although, the Pakistani passport application form contains statement which not only reiterates Khatam-e-Nabuwwat but denigrates MirzaGhulam Ahmad's claim to be a Nabi. ${ }^{\text {xxiv }}$

Blasphemy laws have social implication on the minorities. Some time it was used wrongly or with misunderstanding against accused person. The Blasphemy Laws offences included, with intention insult the religious place of any sect,insulting the religious beliefs of any sect, defiling a copy of the Holy Quran and used the derogatory remarks with respect to the Holy Prophet. The Human Rights Commission of Pakistan monitored the blasphemy cases registered. The Commission's news letter listed fifteen cases against the Ahmadis, five against Christians and eighteen against Muslims. ${ }^{\mathrm{xxv}}$ The activists joined different groups. These activists are involved in violence in Pakistan. The fateful date of 9/11 a nexus of transitional jihad and sectarian groups merged which have close links with military. ${ }^{x v i}$

Christians are also targets of this terrorism wave in Pakistan. A group targeted Sunday Mass in the Dominican Church in October 2001 in Bahawalpur in which 28 worshipers massacred. A terrorist attacked in church service in February 2002 which was attended by mostly foreigners. Terrorists attacked on a school of Christians in Murree Hills on August 5, 2002. The religious bigots had been preaching hatred against minorities and the state is silent in this situation. The failure of democratic process in Pakistan made the responsibilities of civic culture focus on the citizen's rights. There was vacuum of democratic process in early 2000 s, filled by the extremism ride on the Jihad in Afghanistan. It was transnational links with same groups made deep roots in the society. The war on terror in Afghanistan gave fuel to this wave of terrorism. 
In order to deal with the rising phenomenon of sectarianism it is imperative to put a ban on all sectarian organizations that preach hatred against rivals. Sectarian issues should not be allowed to be raised during elections. However, these are temporary measures.

The result of these suicidal policies is that, on the one hand the majority sect is making more and more impossible demands, and, on the process of fragmentation of society along sectarian lines is becoming increasingly dangerous. For instance, a group wants Pakistan to be declared a Sunni state. Further, it wants Section 295-C of the Penal Code enlarged to provide for the death penalty for anyone showing disrespect for the Prophet's (PBUH) companions.

Islam is a universal and a peaceful religion. Islam preaches harmony and safety of life by the state. It is exemplified from history of Islam. The Prophet of Islam entered in Medina though he attempted to reconcile with Jews. The Mithaq-e-Madina was the expression of the Prophet's urge. ${ }^{\text {xvii }}$ This treaty was exemplify to follow in the modern period with tolerance, where Muslims believe that Islam is a religion of peace.

\section{Organized Sectarianism in Pakistan}

The Shia community belong to Peshawar is structured kharis, bilingual Pukhtoons, speaking Hindko and Pushto with equivalent facility and living inside the narrow-lined walled city. They have been captivating the Muharram procession for decades. They performed religious activities without any problem. Shia-Sunni clashes took place in Dera Ismail Khan or Kurram Agency. The rest of the Khyber PukhtoonKhwa and its capital city were known for sectarian synchronization. Political issues did not allow people to indulge in sectarianism. Fierce battles took place in Peshawar when the Shia mourners' processing was fires it approached a Sunni mosque, subsequently few people dead and many injured.

The monster of sectarianism has raised its head and tried to divide and destroy the society of Pakistan: Ground was being prepared for staging Muharram riots all over the country' during the last three months. Just recount the incidents that took place during this period. In May, many leaders belonging to different sects were assassinated in Lahore. A couple of days later a leader of a group was killed in Gilgit in broad daylight. The other group responded within hours, killing the local leader of a group. This led to riots in Gilgit, thirteen persons were killed. In the first week of June there was a clash between a sect and police in Kabirwala, men were rounded up in Karachi for being involved in firing. A local leader was assassinated in Jhang in the mid of June .And 4 persons were killed at KotAddu and at Rahim Yar Khan firing took place between the two conflicting groups. Curfew was imposed in Jhang on 17 June and a few days later army was called. In the second week of July two persons were killed at UchSharif then Peshawar incident occurred which is mentioned earlier.

Whatsoever happened in Peshawar was not in any way unprompted. It was part of a larger venture undertaken by certain elements all over the country to pit the Shia and Sunni communities against each other. Part of the initiative has come from certain internal forces but influences working from outside the country have played greater role in fanning a war that could split the Pakistan which society already divided on ethnic issues. Clashes between 
Shias and Sunnis are not a new phenomenon in Pakistan. But there is a discernible disparity between how they took place earlier and how they are being managed now.

In the past initiative for rioting involving the two communities were always of a local nature Rivalry is belonging to the same area, or a stiff competition between two local influential for a Union Council or an Assembly seat led them to appeal to sectarian sentiments with the result that clashes took place. It was bad luck of local political leaders to promote such sectarian emotion. Now it became a hard job to minimize such emotions.

\section{Talibanization in Pakistan}

The post 9/11 context explains the unexpected political breakthrough of the Mutahid-e-Majlis-e-Amal in the Khyber PukhtoonKhwa in October 2002 elections. ${ }^{\text {xxviii }}$ The MMA out flanked nationalist and secular opponents by decrying the presence of US bases in Pakistan was in the pursuit of the war on terror along with bombings.

Terrorist violence was started from the North-West boundary line and was creeping into the heart of Pakistan in 2007. Imposition of Islamic laws may be the wish of many Pakistanis but the methodology was adopted by the students of Lal Masjid was wrong. First of all they launched a protest against the invasion of Afghanistan in 2001 . $^{\text {xxix }}$ In Islamabad the students of Lal Masjid protested against obscenities like music and movies. These students were favoring the imposition of Islamic law. There were some activities of Lal Masjid authorities which were critical.

In January 2007, female students seized the control of Al-Hafsa library. It was not according to moral and religious values to occupy state property forcefully. In March 27, 2007 a campaign was launched to wipe out the evils from society. The students of Lal Masjid with their spiritual leader were to decide the moralities to shutting down the shops of videos and music. They started to abduct the women who were considered to be immoral character.

Since the government did not take any action against Lal Masjid brigade. This brigade was doing many anti state activities in the functioning system. They were energized to become more active in their supposedly puritan fashion. It was particular case where there was no space for opposite approach people. They pursued the objectives which in essence were not wrong, but this method was not rational. It was said that all this was operate to divert the attention of people of Pakistan from other issues which were painful for government.

There Shariah Courts were set up to carry out judicial proceedings on April 6, 2007. In view of Lal Masjid authorities Islamic Judicial process stated and punished the culprits accordingly. The Shariah court passed judgment against the Federal Minister Tourism NilofarBukhtiar. She committed a sin by embracing her Instructor in the Para shooter show. It was a parallel system of Judiciary in the State. This situation was alarming.

The decision was made to take step against Lal Masjid in the beginning of July 2007. Maulana Abdul Rashid Ghazi was killed on July 11, 2007 and hundreds of innocent lives were lost. The question arises whether both government and Maulana could evolve balanced way. Why it was not adopted. Pervez Musharraf assured to unremitting fight against terrorism 
which required a strong leadership.

It may be said that the religious education system in Pakistan had no checks and balances. The inadequate expansion of state authority was accompained by the traditional institutions, many of which were controlled by the religious leaders in Pakistan. Furthermore, the government's policy of providing the religious leaders with customary stipends incorporated many of them, at least partially, into the state bureaucracy. The students were getting free education. The poorer class masses children came here to get religious education.

On the other hand, Pakistan army heavy handed occupation of the FATA began to alienate local Pashtun tribes. There was shift in alliance between the government and local militants, the situation was confusing. A long list of assassinations of moderate and elder tribal leaders gave the sign of Talibanizations creeping in the society. The fear of spreading of Talibanization in the settler areas was a main cause of fear at government level. In this regard new policy was implemented in FATA drawing a counter insurgency model by incorporating generous development assistance, political overtures and a relocation of army from population centers. ${ }^{\mathrm{xx}}$ Taliban gave examples of leadership of Hazrat Mohammad (PBUH) Holy Prophet of Muslim Ummah for jihad. It was time when Islam was at initial stage. Hazrat Mohammad (PBUH) has position with the combination of both spiritual and temporal authority. ${ }^{\text {xxi }}$ Preaching against the religious groups causes creation of Taliban which damage the security system of states. To handle this issue USA and its allies used carrot and stick policy to counter the threat of terrorism. Economic measures are taken to stabilize Pakistani economy. Therefore, it was perceived that due to lack of public schools, children get education from Madrassahs. ${ }^{\text {xxii }}$

Talibanization affected Pakistan's security system. The masses of Pakistan were much afraid of the situation. Taliban were aggressive against Pakistan. On the pressure of USA and his allies Pakistan blocked across border support to Taliban. Taliban started their activities in Pakistan. The series of suicide bombing took place in Pakistan. Khyber PukhtoonKhwa and Punjab were affected from the wave of terrorism. There were more than 140 suicide attacks made in Pakistan in which there were 1700 victims in 2002 to 2008. This situation is alarming for Pakistan. ${ }^{\text {xxiii }}$ Ehud Sprinzak pointed out in his article that it was important not to succumb the idea that they were ready to do anything and lose everything. ${ }^{\text {xxiv }}$ It was debatable that incentives for self-martyrdom were religious or political, altruistic or personal. Martha Creenshaw also resorted to terrorism would not be an aberration. ${ }^{\mathrm{xxx}}$ Terrorism is subject of analysis in international affairs as like guerrilla war but suicide terrorism has its own laws.

The Taliban targeted by suicide bombing there are three types of suicide bombings targets: the State, US presence and religious or sectarian opponents. ${ }^{\text {xxvi }}$ The ratio of suicide bombing was in the Khyber PukhtoonKhwa 41\% Punjab 21\% and 19\% in FATA from 2002 to $2008 .^{\text {xxxvii }}$

\section{Operation Bajaur}

Pakistan is facing full scale war on its western border. The remote corner of Pakistan is the 
main cause of critical situation for the government of Pakistan and it is the test of Pakistan's military determination to face the challenge. There was an attack of bombing on Marriott Hotel Islamabad, It was devastating terrorist attack in which 53 people were killed and proved a failure of security in Islamabad. Several military officials say that Bajaur is a litmus test. Its success or failure would decide the fate of people of tribal area. Like Waziristan, Bajaur is strong hold of militants in the tribal belt after successful operation in Waziristan. Pakistani Army used tanks and air fighters in the region. The military officials were astonished at the sophistication of tactics, weapons resistance and communication system. Their weapons and means of communications are better than official weapons. Even the use of sniper rifles is better than of ours. They were fighting like organized force. ${ }^{\text {xxxviii }}$

Pakistan had lost the hundreds of its soldiers in the tribal belt since the American military chased the Taliban and Al Qaeda in the Afghanistan 2001 and 2002. The public and civilian losses have shaped the government's appetite for launching a main scale military operation. The tendency of fight to draw and sue for peace context government and military has done peace deals. Critics say that they feel stronger after the peace deal.

\section{Operation Waziristan}

As Waziristan consists of two parts;North Waziristan and South Waziristan, The North Waziristan consists of Miranshah, Razmak, DattaKhel, Spin Wam, Dosali, Shawa, Shawal, and Dawrs and South Waziristan has Wana district headquarter.

It was for the first time when Pakistani army moved to South Waziristan to attack the Afghan Taliban and Pakistani Taliban in March 2004. As a result, there was revolt against Pakistan under the local leadership of Taliban. In the battle several villages were destroyed and hundreds of people and children were injured. Facing hardships government made peace deals with the fighting persons. First deal was made with Niek Mohammad Wazir guaranteeing to withdraw of troops and amnesty for foreign Taliban. The US government swayed to attack. They allegedly perfidy on the part of Pakistani government and abrogated the agreement. This deal was dropped when Niek Mohammad was killed in missile attack in April 2004. There was a fighting between Pakistani government and Taliban. Then government made another deal with Beit-UllahMasud in September 2006 which extended to North Waziristan.

National Security Council decided operation in Waziristan on June 4, 2007. In the meeting Talibanization in the region and crushed militancy in the region was discussed. The government is trying to maintain law enforcement situation in the area. The government was providing modern weapons to law enforcements and was trying to block the broadcast of radio channels. ${ }^{\text {xxxix }}$ The operation Sirat-e-Mustaqeem was launched in Bara Tehsil of Khyber Agency on June 28, 2008. It was halted on July 9, 2008. ${ }^{\mathrm{xl}}$ Taliban and other groups were operational in the region. ${ }^{\text {xli }}$

It was noted that till December 2006 nearly 750 soldiers of Pakistan army lost their lives in military operation since 2001 in Federal Administered Tribal Areas in which Waziristan is hot pot of the areas. ${ }^{\text {xlii }}$ The total loss was more than $1000 .{ }^{\text {xliii }}$ This conflict was bloodier after 
using of suicide bombing against the military forces. The military and security forces were responding and using gunships helicopter and long range artillery guns. The bloodshed spread to those places which were sacred and untouched. ${ }^{\text {xliv }}$ To maintain peace in the region Pakistan army followed the airstrike which scrapped the Tribal Taliban in September 2006. In July and August 2007 in attacks 250 Taliban and 60 soldiers lost their lives. In July 2007 Peace Accord was signed with Wazir Tribe. In September 2007, 247 soldiers in 17 vehicles were abducted by Taliban. The different Taliban groups made alliance and BeitUllahMasood was made a leader as Amir. Now Tehreek-e-Taliban Pakistan was established in December 2007.

It was an alarming situation for the security institutions. It was need of the hour otherwise both the soldiers and Taliban have lost their lives. There were attacks and counter attacks. The situation of security was so poor that security forces itself concerned how to protect from suicide bombing in the fight against the militants. ${ }^{x l v}$ For this situation there were many factors regarding interpretations. Excessive use of firepower was by the armed forces which disturbed the large segment of tribal population. ${ }^{\text {xlvi }}$ Local Taliban Commander say, "Pakistan knows everything about us, but is ignoring us". xlvii

\section{Negotiation with Taliban}

It was debated in the policy making process of USA about Taliban groups those were sustaining in Afghanistan ingrained in the Federally Administered Tribal Area and Khyber PukhtoonKhwa Province. ${ }^{\text {xlvii }}$ America pressurized Pakistani government opted the strategy of negotiation with some groups of Taliban. These Taliban gave up arms. Pervez Musharraf had adopted the policy of 'carrot and stick, to divide the Taliban and regained the control of FATA. Pervaiz Musharraf government motivated Taliban to be incorporated in to Pakistan which changed the status of the area. The covenant with Taliban was divergent by the US government. It smacked of pacification and weakness; it institutionalized the protective gains made by Taliban. It was not accepted by the US officials because in this way Afghan Taliban could not become weak against the non-Taliban government of Afghanistan.

\section{Operation Swat}

Pervez Musharraf's strategy for FATA was ambivalent. Because of majority of people of Pakistan were not in favor of deployment of armed forces in the region. They thought that negotiation should be used to handle these young men. The reign of terror made people against the Taliban. US military strike and raids were unpopular in the public. The connection between Pakistan extremist and Afghan Taliban was cleared after the tragic incident of Lal Masjid in July 2007. At this Fazalullah led the Tehreek-e-Nafaz-e-Shariat-e-Mohammadi in open revolt and obtained the control of Swat. First time he declared war against the Pakistani government in January 2006. When his brother was killed in drone attacks.

The Tehreek-e-Nafaz-e-Shariat-e-Mohammadi operated in the Swat district for the enforcement of Islamic Laws. There was cease fire signed on May 22, 2007. ${ }^{\text {xlix }}$ Fazalullah came back in Swat and started activities against the people who supported army operation in Swat. 
This situation broke the peace accord between TNSM and provincial government. There was destruction in Swat. Hundreds of people were driven out from Swat. Approximately 238 schools were burnt. Many people were occupied and turned into militants bases.

There was anxiety at internal level to block the activities of terrorists. It was decided that the federal security institutions would maneuver in this region. The Taliban militants took over the control of Buner, Lower Dir, Swat and Sangla, it was taken back and refurbish the injunction of government. In November 2007 Pakistan Army launched a fully-fledged operation in Swat. The Army destroyed Taliban's head quarter.

After February 2008 elections, ANP formed coalition government. There was ceasefire between army and the government. The Provincial government was agreed to implement Shariah in the region. The violence standoff with army in Swat continued till negotiation of the Nizam-e-Adl Agreement in February 2009 under which the Shariah law became legal code in the Malakand Division. This agreement stopped the violence. Sufi Mohammad arrived Swat to negotiate with FazalUllah for peace process. TTP announced to observe ceasefire. The provincial government passed a bill and sent to President Asif Ali Zardari for approval. President waited till the revival of writ of government. Taliban started expanding areas of Buneer, Lower Dir and Shangla. In April 2009 Taliban sent hundreds Taliban from Swat to Buner to South East which is 70 miles away from Islamabad. Motorway was nearby which linked Peshawar and Islamabad and Tarbela Dam. It was seemed that Taliban may be able to capture Islamabad. The situation was becoming alarming for the West.

The critical and turning point seemed to arrive at a meeting in July between the coalition government officials and chief of army staff General AshfaqParvezKayani. In the meeting General Pervez assured full confidence to the government to tackle the problem of militants. It was up to government to decide time and method to choice to tackle the problem. President Bush pressured under the policy of carrot and stick to operate in tribal areas. The operation Bajaur proved the restoring of the military credibility to stop insurgency at home or abroad. Failure or abandonment of the operation brought disastrous and situation became emboldened for the militants. ${ }^{1}$

This situation was intensified between security forces and Tehreek-e-Taliban Pakistan in 2009. Washington stressed Pakistan and Pakistani government to start operation to obtain all territories of region which were under control of Taliban. An aggressive military operation Black Thunderstorm was commenced on April 26, 2009. Till mid summer of 2009 the military had driven away TNSM from Swat. USA started drone attacks on the safe heavens of terrorists in the region of FATA. Many terrorists were killed in these attacks. First Amir of Taliban TehreekBeit- UllahMasood was killed in drone attack in August 2009. Now Hakim-UllahMasood took over leadership of TTP. Violence was no longer cramped in the tribal belt of Pakistan and Afghanistan.

It was estimated that 1400 militants were killed in military operation which were launched in April 26, 2009. Due to military action 3.8 million people were fleeing their home in the search of safety and security. It was initially confined to Lower Dir, Buner and Swat Districts of Khyber PukhtoonKhwa. Next it would be spread to rest of FATA and KPK. The Security 
Forces continued their operation. TTP gave response with flurry of attacks in all over Pakistan. These attacks were spread to Punjab. It was reported that in the first half of 2009, 155 persons in which 92 civilians and 51 Security Force personnel were killed. There were 104 incidents in which 9 in Islamabad and 18 in Lahore reported. There were 12 terrorists in which 9 suicide bombers were killed. The terrorists attacked on the garrison town of Rawalpindi, capital city Islamabad and Pakistan heart Lahore reported. li

The situation was alarming in FATA for Pakistan government, America, NATO and pro-Pakistani tribal leaders. The convergence of ethnicity, Islamist fundamentalism, Pashtun nationalism and a wave of hatred to the west fostered by Al Qaeda had created a different situation for Pakistan. India found easy way in consternation in Kashmir, division between militants prolong the conflict.

\section{Policy of Awami National Party}

KhudaiKhidmat Gar movement was ally of Indian National Congress party. This connection was not regarded in Pakistan. ${ }^{\text {lii }}$ It was changed into National AwamiParty in 1970's. It was Pashtun nationalist party. ${ }^{\text {liii }}$ ANP associated with USSR in 1970's and developed conflict with Pakistani establishment at the issue of Afghan Taliban. ${ }^{\text {liv }}$ It was strange situation when Awami National Party oadopted policy to negotiate with Taliban Pakistan for peace process in the election of 2008. It was horror of conducting civil war in Pakistan. It was ANP's national policy for non-violence. ANP had influence of Pakistan Army. The Pakistan army's unwillingness was to launch such war with alliance of USA forces. Many workers and leaders of ANP were killed in Swat and other places of Khyber PukhtoonKhwa. The situation forced ANP to change the policy in KPK. It was calling for military operation in May 2009 and condemning every action of terrorism which caused civilian casualities. There was discussion in the assembly on August 19, 2008, for terrorist activities in the province for policy making. Different leaders of ANP had different approach about the activities of Taliban in the Khyber PukhtoonKhwa. Few leaders claimed as BushraGohar that Pakistan army should have to block the activities of Taliban in the Province. In her view, ISI could manage to close the training camps of Taliban.

\section{Policy of Pakistan Muslim League}

The Muslim League, however, had stressed both their moderate Islamist and their nationalist credentials, seeking thereby to contrast them with the' Westernized' Bhutto. Nawaz Sharif also distanced himself from the alliance with the US War on terror and the campaign against the Pakistani Taliban without categorically opposing them in 2007. The PML (N)'s support for talks and distancing from the US form part of a strategy, emphasized to seeking to undermine both the Pakistani Taliban and the JamaatIslami by drawing away their supporters into mainstream politics. It was estimated by PML $(\mathrm{N})$ leadership in the elections of February 2007 which were boycotted by JamaatIslami, 40\% of Jamaat voters nonetheless turned up to vote PML $(\mathrm{N})$. which was benefited by PML $(\mathrm{N})$.

The party was not making any visible headway in winning over the violent radicals, who had long moved beyond the reach of Pakistani mainstream politics. However, this strategy did 
seem to have considerable success and the soaring popularity of the PML $(\mathrm{N})$ in polls in 2008-09 owed a good deal. The perception was that Nawaz Sharif 'would defend Pakistani interests. He never surrendered them like Musharraf and Zardari. This perception was a cause of increasing popularity of PML (N) in the KPK and party's chances of permanently expanding beyond its Punjabi base. It was the impact of war on terror in the region. Pakistan Muslim League (N) was prevailing positive impact in politics.

The western observers and Pakistani liberals fear in the PML(N) will turn Pakistan away from the alliance with the US, and towards a much more Islamist system at home, as introduced by General Zia-ul-Haq. The Pakistani industrialist groups who supported Nawaz Sharif knew the cost of decisions in the radical break with the US. Every segment of society was affected by such decisions of political leaders. The decisions were made on the basis of the best interest, durable and longtime perception for the betterment of nation.

Pakistani business community also knew how Pakistan is dependent on US aid, and although they will undoubtedly tried for greater distance. The policies of leadership of PML.N towards the Afghan Taliban were likely to be much the same mixture as those of Musharraf and Zardari. The Sharifs' business and 'feudal' support also meant that unlike the JamaatIslami and the Taliban they could not even flirt with ideas of Islamist social and economic revolution.

It was a threat to law and order situation in Punjab. The government of Punjab was trying possible effort to maintain the law and order situation. The people feel secure on this issue. It was felt that it was not our war. We were dragged for the participation in the war. Shahbaz Sharif stated publicly on March 2010 that Musharraf planned a bloodbath of innocent Muslims. The blood cast of others to prolong his rule. The PMI(N) opposed his policies and rejected dictation from abroad and if the Taliban were also fighting for the same cause then they should not carry out acts of terror in Punjab. These statements were an obvious attempt to get the Pakistani Taliban and their allies to stop attacking Punjab and concentrate on other provinces.

The PML (N) government's failure to prevent massive terrorist attacks in Punjab will undermine its prestige as a 'party of law and order', and while many Punjabis with whom have spoken continued to support talks with Pakistani Taliban even after they began to attack Punjab, it is not certain that this will continue if they kill more and more innocent people and target such sites as Data Ganj Bash. In July 2010, following Pakistani Taliban attack on the great shrine of Data GanjBaksh in Lahore which killed forty-five worshippers.

\section{US Drone Attacks in Pakistan}

The operations of drone attacks were in the control of Central Intelligence Agency's division which controls the Special Activities ${ }^{\text {lv }}$. It was the part of war on terror. The Government of Pakistan publicly condemned drone attacks. It was reality till Aril 21, 2011 the attacks were

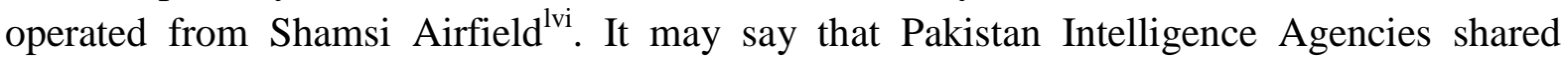
intelligence with CIA. The United States government engages a clandestine war in the Northern areas of Pakistan. FATA's areas coupled with Afghanistan border and compassionate 
population of Pashtun. This is key insurrectionary element and terrorists organizations allegedly tied with Al Qaeda. USA beleaguered with airstrike to senior and top leadership of Al Qaeda which were taking sanctuary in the areas. It was according to the variety of actions policy for the counter terrorism. Pakistan was also conducting operation in South Waziristan, Bajaur, Swat and other FATA areas. Pakistan's growing crisis of governability is disturbing the policy makers across the world.

A group of top US experts on Pakistan conclude that "The United States cannot afford Pakistan to fail nor...ignore the extremists operating in Pakistan's tribal areas" to operate

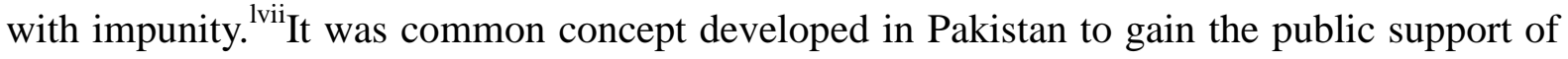
Pakistani in the case of US drone attacks. US drone attacks have special impacts in the internal situation of law and order. Taliban used these attacks in favor of them. The major source to combat the terrorist groups is drone attacks in the northern areas of Pakistan. It is a great debate about the drone attacks in the Northern Areas of Pakistan. Many political leaders of Pakistan think that the attacks are against the sovereignty of Pakistan.US Drone Strike Statics estimated, New American Foundation Analysis of Newspaper. ${ }^{\text {lviii }}$

Pakistani government requirement is to endow heavily in equipping law enforcement agencies with modern technologies to probe suicide attacks. There was a need of hard work at intelligence agencies to unearth the suicide networks. Suicide work is merely not a motivated by religious leaders, it is a multi-dimensional phenomenon involved by political, cultural, economic and social factors. After several studies it was revealed that revenge factor, disenchantment with government policies. The poverty and educational factors were also involved in the terrorist activities of suicide bombing. Public awareness about these types of activities is essential element to block or minimize the activities. The electronic and print media can play a vital role to educate the masses.

The drone attacks enhanced the terrorist activities because innocent killing of innocent people of Pakistan rages the feeling of people against the policy of war on terrorism in Pakistan.

\section{REFFERENCES}

i. Davis, Anthony. (1998). How the Taliban Became a Military Force.in William Maley, ed., Fundamentalism Reborn.Afghanistan and the Taliban. New York: New York University Press. pp. 44-46, 61-62.

ii. Rumsfeld, Donald, H., (2001). A New Kind of War. New York Times, September 27, 2001. http://www.nytimes.com/2000/09/27/opion/27RUM.html. International Security, Vol.26, No3 (Winter2001/02), pp. 79-93? 2001 by the President and Fellows of Harvard College and the Massachusetts Institute of Technology.

iii. Terrorism in Southwest Asia 185.

iv . Laqueur, Walter. (1999). The New Terrorism: Fanaticism and the Arms of Mass Destruction. New York: Columbia University Press. pp.127-129.

v . Bob,Woodward. (2002).Bush at War. New York: Simon \&Schuster.pp. 58-59.

vi . Ahmad, Samina. (2001). Nuclear Proliferation in South Asia: U.S. Policy Challenges. Foreign Policy in Focus. Vol. 6, No.28 (July 2001). p.2. 
vii. Mohan, C., Raja. (2001). Bush Proposal Aimed at Rogue States.Armitage, Hindu, May 21, 2001, http://www.hinduonnet.com/thehindu/2001/05/stories/0121006.html

viii. Jennife,Elsea. (2001). Terrorism and the Law of War: Trying Terrorists As War Criminals. CRS Report for Congress updated December 11, 2001, before Military Commission.

ix . A Report of the Pakistan Policy Working Group. (2008). The Next Chapter, United States and Pakistan. United States Institute of Peace.p.23.http://www.usip.org/pubs/ppwg_report.pdf

x. Pakistan withdrew its support for Peshawar based Pasrun parties when they failed to dislodged Rabbani's regime from Kabul and subsequently created and supported the Taliban militia against long standing allies such as Hezb-e-Islami'sGulb-ud-din HekmatYar. http://www.usip.org/pubs/ppwg_report.pdf

xi Support to continue until Military Targets Achieved: CE, Dawn, October 17, 2001. http://www.dawn.com/2001/10/17/top2.html

xii . Walsh, Declan. (2010). Pakistan suffers record number of deaths due to militant violence. The Guardian, January 11, 2010.

xiii . Islamabad, Kabul looks inwards as Tehran blames US, Express Tribune.

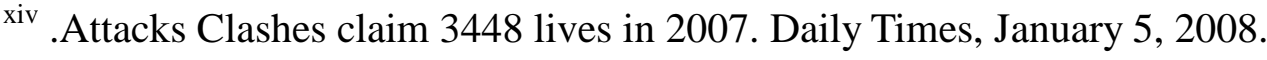

${ }^{\mathrm{xv}}$ Siddiqi, Muhammad, Ali, 8000 dead: is the world aware? Dawn January 27, 2009.

xvi .Khan,Javed, Aziz, 880 Killed 2070 hurt in 61 suicide attacks this year. The News December 22, 2008.

xvii . A bomb attack leaves at least 45 Sunni worshipers dead. The Guardian. November 2009.

xviii. Daily Jang Lahore. February 5, 2010.

xix . Alex, Rodriguiz. (May 23, 2011). Militants storm naval base in Pakistan. Los Angeles Times.http://www.latimes.com/news/nationworld/world/asia/la-fg-pakistan-attack-

20110523,0,1920099.story.

${ }^{x x}$. Mir, Amir. (July 3, 2009). Pakistan turned into suicide capital of the world. Middle East Transparent.

http://www.metransparent.com/spip.php?page=article\&id_article=7514\&lang=en

xxi . Daily Jang Lahore, February 1, 2010.

xxii. Sectarian Violence in Pakistan 1989-2011, South Asian Terrorism Portal, http//www.sp.org/satporgtp/countries/Pakistan/databases/sect-killing.htm Access April 26, 2011.

xxiii. Amnesty International.(1994). Pakistan: Use of Blasphemy Laws. New York: Amnesty International. pp. 6-7.

xxiv . Malik, I.H., (2002). Religious Minorities in Pakistan. London: Minorities Rights Groups International. p. 22.

xxv . HRCP, (2000). Newsletter 11, no 4 (October 2000): 13-14.

${ }^{x x v i}$. Shafqat,S., (2002). From official Islam to Islamism: The Rise of Dawat-ul_Irshad and 
Lashker-e- Taiba. inJaffrelot. C (ed) Pakistan Nationalism without Nation? New Delhi: Manohar. pp. 131-148.

${ }^{x x v i i}$ Watt, W. Montgomery. (1981). Muhammad at Madinah, Karachi: Oxford University Press. p.198-204.

xxviii . Talbot, I., (2003).Pakistan in 2002: Democracy, Terrorism and Brinkmanship. Asian Survey, 43, 1: pp 198-208.

xxix . Abbas, Zafar. (2007). The Creeping Coup, Dawn, Pakistan. March 31, 2007.

${ }^{x x x}$. Markey, Daniel.(2007). A False Choice in Pakistan, Foreign Affairs.Vol. 86, No. 4 (Jul. - Aug., 2007), Pp. 85-102 Published by: Council on Foreign Relations. URL: http://www.jstor.org/stable/20032417 .Accessed: 24/04/2012 06:47

xxxi. Zakaria, F., (2003).The Future of Freedom: Illiberal Democracy at Home and Abroad. New York and London: Norton. p.147.

xxxii. Rashid, Ahmad.(2001). Pakistan, the Taliban and the U.S. Nation. October 8, 2001. http:// www.nation.com.pk/archives.html.

xxxiii. Amir, Mir. (2008). Pakistan tops Iraq, Afghanistan in Suicide Bombing Deaths. The News September 15, 2008. http://www.thenews.com.pk/daily_detail.asp?id=135

xxxiv . Ehud, Sprinkzak. (2000). Rational Fanatics.ForeignAffairs.September-October. 120:73.

xxxv. Martha, Creenshaw. (1990). The Logic of Terrorism: Terrorist Behavior as a Product of Strategic Choice.In Walter Rieched.Origins of Terrorism: Psychologies, Ideologies, Theologies, State of Mind. Cambridge: Cambridge University Press. p.10.

xxxvi. Death of Mufti Naeemi.Daily Times June14, 2009.

xxxvii. Gayer, Laurent. (2009). Pakistan: Du Desordre a La Guerre Civile? IFRI Focus Strategique n 14.February. P.5.

xxxviii. Khan, Ismail \& Gall, Carlotta. (2008). New York Times on line, September 22, 2008 http://www.nytimes.com/2008/09/23/world/asia/23assess.html?_r=1\&ref=world\&oref=slogin

xxxix. Khan, Ismail.(2007). Plan Ready to Curb Military in FATA, Settled Areas. Newsweek international edition.www.Dawn.com.http://www.dawn.com/2007/06/26/top4.htm.Retrieved 2007-06-27.

${ }^{\mathrm{xl}}$.Killing the hydra headed monster of militancy http://tribune.com.pk/story/11838/killingthe-hydra-headed-monster-of-militancy/.

${ }^{x l i}$.Operation Sirat-e-Mustaqeem Avoids Targeting Taliban by Sindh Times. http://www.sindhtimes.com/news/120/ARTICLE/1977/2008-07-11.html xlii. The Frontier Spirit, Economist, December 13, 2006, http://www.economist.com/world/ asia/ Printer Friendly.cfm?story_id _ 8413130 _ xliii.Where the Jihad Lives Now, Newsweek, October 29, 2007. http://www.newsweek.com/ id/57485

xliv. Yousifzai, Rahimullah, Jirga still the Best operation in Waziristan. News International Pakistan. August 17, 2007.

xlv . Militants Release 25 Pakistani Soldiers, Dawn Pakistan. September 21, 2007.

xlvi. Where the Jihad Lives Now Newsweek.21, 2007. 
xlvii. Where the Jihad Lives Now Newsweek.21, 2007.

xlviii. Markey, Daniel.(2008). Securing Pakistan's Tribal Belt.

Council on Foreign Relation Report No.36. August 2008. https://secure.www.cfr.org/content/publications/attachments/Pakistan_CSR36.pdf

xlix.Sectarian Violence in Pakistan 1989-2011, South Asian Terrorism Portal, http//www.sp.org/satporgtp/countries/Pakistan/databases/sect-killing.htm Access April 26, 2011.

1. Khan, Ismail \& Gall, Carlotta.(2008). op.cit.,p.11.

li. Laxman, Kanchan.(2009). Afflicted Power, South Asia Intelligence.Review Weekly Review, Vol. 7 (49). June 15, 2009.

lii Banerjee, Mukulika. (2000). ThePathan Unarmed: Opposition and Memory in North West Frontier. London: James Currey.p.32.

liii. White, Joshua, T., (2008).Pakistan's Islamist Frontier, Islamic Politics and US Policy in Pakistan North West Frontier, Religion and Security Monograph Series 1. Arlington VA: Center on Faith and International Affairs. pp. 96-97.

liv . Najom, Neamatollah.(2002). The Rise of Taliban in Afghanistan-Pakistan's leftists and the Soviets. New York: Palgrave Trademark.p.55.

lv . Bobby, Ghosh, \& Mark, Thompson.(2009). The CIA's Silent War in Pakistan. Time http://www.time.com/time/printout/0,8816,1900248,00.html.Retrieved December 16, 2011.

lvi . Amanda, Hodge.(2009).Pakistan allowing CIA to use airbase for drone strike.Australian.http://www.theaustralian.com.au/news/pakistan-permits-cia-base-forstrikes/story-e6frg6t6-1111118893683. Retrieved December 6, 2011.

lvii. A Report of the Pakistan Policy Working Group, (2008).The Next Chapter, United States and Pakistan.United States Institute of Peace, September 2008. http://www.usip.org/pubs/ppwg_report.pdf.

lviii . The Year of the Drone: An analysis of U.S. Drone Strike in Pakistan 2004-2012. New America Foundation. http://counterterrorism.newamerica.net/drones. Retrieved July 24, 2012. 